\title{
ОБЗОРЫ
}

\section{Эмпирические исследования структуры капитала компаний на развивающихся рынках: специфика и методология}

\author{
Герасимова C.M. ${ }^{25}$
}

\begin{abstract}
В данной статье представлен обзор ряда последних работ, посвященных проблеме формирования структуры капитала на развивающихся рынках. Систематизированы специфические черты развиваюшихся рынков капитала, существенные для анализа проблемы структуры капитал. Показань особенности применения методологии эмпирических исследований структуры капитала на развивающихся рынках капитала. Приведень результаты ряда недавних эмпирических исследований структуры капитала на развивающихся рынках капитала. Обобщение выводов ряда последних работ, посвященных проблеме формирования структуры капитала на развиваюшихся рынках, позволит учитывать специфику таких исследований при дальнейшем анализе структуры капитала на развивающихся рынках.
\end{abstract}

JEL: $G 30$

Ключевые слова: структура капитала, развивающиеся рынки капитала, компромиссная конщепциия, конщеепџия иерархий

\section{Основные черты развивающихся рынков капитала, влияющие на процесс формирования структуры капитала}

Изучение структуры капитала компаний, работающих на развивающихся рынках, вызывает интерес у исследователей в связи с отличием стран с развивающимися рынками капитала от развитых стран. Исследователи ставят вопрос о том, есть ли какие-либо специфические для данных рынков факторы и концепции, или же для структуры капитала компаний развивающихся стран применимы теоретические концепции, используемые компаниями развитых стран. Кроме этого, исследование структуры капитала развивающихся рынков позволяет посмотреть на процессы корректировок структуры капитала, происходящие в результате изменения факторов, в процессе развития рынков.

Факторы, влияющие на структуру капитала, можно условно разделить на факторы, определяемые внешней и внутренней средой компании. Как правило, для выявления специфики факторов на развивающихся рынках эти рынки сравнивают с США или другими развитыми странами. Далее будут рассмотрена специфика развивающихся рынков в соответствии с факторами структуры капитала.

\section{Факторы, определяемые внешней средой}

Рынки капитала. Для развивающихся стран характерна неразвитость рынков капитала и кредитно-денежных институтов. Поэтому даже когда компании видят выгоды от корректировки структуры капитала, такие корректировки могут оказаться невозможными изза отсутствия доступа к соответствующим источникам финансирования.

Например, исследователь Чакраборти I.Chakraborty (Chakraborty, 2010) пишет о том, что рынок капитала Индии начал развиваться только после 1992 года. Кроме того, за период

\footnotetext{
${ }^{25}$ Аспирант кафедры экономики и финансов фирмы НИУ ВШЭ.
} 
с 1995 по 2008 год произошли реформы в банковском секторе. Все это привело к существенному изменению в структурах капитала компаний. Делькур N.Delcure (Delcure, 2007) отмечает, что для стран с переходной экономикой, таких как Польша, Чехия, Словакия, РФ, отношение капитализации фондового рынка к ВВП ниже 3\%. По данным Ни, Гуо, Джилеса Y.Ni, S.Guo, D.E.Giles (Ni, Guo, Giles, 2010) рынок капитала в Китае относительно молодой; кроме того, в Китае существует ограничение при допуске компаний к размещению. Ву, Йу (Wu, Yue, 2009), описывая специфику Китая, подчеркивают, что рынок корпоративных облигаций практически не существует (менее 1\% от ВВП в 2005 году). Спрос на банковские кредиты существенно выше, чем предложение. Сеспендес, Гозалес, Молина (Cespendes, Gozales, Molina, 2010), исследовавшие страны Латинской Америки, также отмечали неразвитость рынков капитала. Удомсирикул, Джамреорнвонг, Джирапорн (Udomsirikul, Jumreornvong, Jiraporn, 2011), сравнивая рынок капитала Таиланда с рынком капитала США, учитывали молодость и неразвитость рынков капитала. Оях, Пиллай (Ojah, Pillay, 2009) говорят, что формирование рынка корпоративных облигаций в Южной Африке происходило в конце 1980-х - начале 1990-х годов. Элдомьяти (Eldomiaty, 2011) пишет о неразвитости рынков капитала в Египте. Амир (Ameer, 2010) изучает влияние либерализации рынков капитала на изменения в структуре капитала в 12 развивающихся странах ЮгоВосточной Азии и Южной Америки.

Правовая система. В развивающихся странах уровень правовой системы и эффективность закона о банкротстве достаточно низки по сравнению с развитыми странами, поскольку правовая система находится в процессе становления. Влияние данного фактора отмечали Харви (Harvey, 2004), Делькур, Сеспендес, Гозалес, Молина.

Коррупция. Уровень коррупции в большинстве развивающихся стран значительно выше, чем в развитых. Данная специфика учитывается в работах Удомсирикула, Джамреорнвонга, Джирапорна, Делькур, а также Окере, Тамуле, Малоней (Okere, Tamule, Maloney, 2010).

Макроэкономическая нестабильность. Макроэкономическая нестабильность и высокая инфляция в развивающихся странах способствуют росту неопределенности у инвесторов и кредиторов. Влияние высокой инфляции отмечает Делькур. Исследователи Сеспендес, Гозалес, Молина, изучавшие страны Латинской Америки, подчеркивают, что высокая волатильность экономики снижает финансовые возможности компаний. Окере, Тамуле, Малоней говорят о проблемах макроэкономической нестабильности и высокой инфляции в развивающихся странах. Стефан, Талавера, Цапин (Stephan, Talavera, Tsapin, 2011) изучают предпочтения и возможности компаний привлекать заемное финансирование с разными сроками погашения в Украине, где компании оперируют в специфических условиях, характеризующихся высокой макроэкономической нестабильностью.

Налоги. В некоторых развивающихся странах наблюдаются изменение в уровне налоговых ставок и льгот, что может стимулировать изменение структур капитала компаний. Сеспендес, Гозалес, Молина замечают, что, по сравнению с США, компании Латинской Америки имеют меньшие выгоды от налоговых щитов. Ву, Йу изучают влияние изменения в налоговой политике Китая на структуру капитала компаний. Делькур также сравнивает изменения в налогах в странах с переходной экономикой.

Информационная прозрачность. В большинстве развивающихся стран учетная политика и требования к раскрытию информации остаются низкими. Кроме того, количество аналитиков, освещающих компании, в развивающихся странах существенно меньше, чем в развитых. Так, Раджагопал (Rajagopal, 2011) отмечает недостаточное аналитическое обслуживание банков Индии и высокие уровни информационной асимметрии. Лопес, де Аленкар (Lopes, de Alencar, 2010) говорят о неравномерном уровне раскрытия информации компаниями в Бразилии. 
Специфика некоторых внешних факторов компании на развивающихся рынках капитала

\begin{tabular}{|c|c|c|}
\hline Фактор & Развивающиеся рынки & Развитые рынки \\
\hline \multicolumn{3}{|c|}{ Наличие ограничений и транзакционных издержек, связанных с доступом к капиталу } \\
\hline $\begin{array}{l}\text { Развитость } \\
\text { рынков акций } \\
\text { и } \\
\text { корпоративных } \\
\text { облигаций }\end{array}$ & $\begin{array}{l}\text { Рынки слабо развиты, так как: } \\
\text { - } \quad \text { Рынки относительно } \\
\text { молодые (сформированы в конце } \\
80-\text { - начале 90-х годов ХХ века) } \\
\text { • Доля рынков капитала в ВВП } \\
\text { стран очень низка (в некоторых } \\
\text { странах составляет } 1-3 \%)\end{array}$ & $\begin{array}{lr}\text { Рынки капиталов } & \text { имеют } \\
\text { длительную историю, считаются } \\
\text { высокоразвитыми } \\
\text { соответственно, существенно более } \\
\text { эффективными, чем } \\
\text { развивающихся стран; отличаются } \\
\text { высокой капитализацией }\end{array}$ \\
\hline $\begin{array}{l}\text { Развитость } \\
\text { банковской } \\
\text { системы }\end{array}$ & $\begin{array}{l}\text { • } \\
\text { бонопольное } \\
\text { банков по отношению к компаниям } \\
\text { • } \quad \text { Важная } \\
\text { отсутствия } \quad \text { афф наличия или } \\
\text { банков с компаниями } \\
\text { • } \quad \text { Высокие процентные ставки } \\
\end{array}$ & $\begin{array}{llr}\text { Развитая } & \text { банковская } & \text { система; } \\
\text { высокая } & \text { конкуренция } & \text { между } \\
\text { банками } & & \end{array}$ \\
\hline \multicolumn{3}{|c|}{ Уровень развития правовой системы } \\
\hline $\begin{array}{l}\text { Защита прав } \\
\text { собственников } \\
\text { и кредиторов }\end{array}$ & $\begin{array}{l}\text { В большинстве развивающихся } \\
\text { стран - низкая }\end{array}$ & Высокая \\
\hline $\begin{array}{ll}\text { Закон } & 0 \\
\text { банкротстве } & \\
\end{array}$ & $\begin{array}{l}\text { В ряде развивающихся стран } \\
\text { остается неэффективным }\end{array}$ & Эффективный \\
\hline Коррупция & $\begin{array}{l}\text { В большинстве } \text { развивающихся } \\
\text { стран - высокая (развивающиеся } \\
\text { страны находятся на последних } \\
\text { местах в рейтинге стран, } \\
\text { составленном на основании индекса } \\
\text { СРI) }\end{array}$ & Низкая \\
\hline $\begin{array}{l}\text { Макроэкономи } \\
\text { ческие } \\
\text { факторы }\end{array}$ & Высокая нестабильность & Относительно стабильные \\
\hline Налоги & $\begin{array}{l}\text { Происходит становление налоговой } \\
\text { системы, поэтому уровень налогов } \\
\text { может меняться }\end{array}$ & Установившаяся налоговая система \\
\hline \multicolumn{3}{|c|}{ Степень информационной прозрачности } \\
\hline $\begin{array}{l}\text { Раскрытие } \\
\text { информации } \\
\text { компаниями }\end{array}$ & $\begin{array}{l}\text { Низкий уровень информационной } \\
\text { прозрачности, } \\
\text { дифференциация между уровокая } \\
\text { раскрытия информации разных } \\
\text { компаний }\end{array}$ & \begin{tabular}{lr} 
Высокие & \multicolumn{2}{r}{ законодательные } \\
требования $\quad$ к & раскрытию \\
информации & \\
Высокий уровень \\
информации
\end{tabular} \\
\hline $\begin{array}{l}\text { Освещение } \\
\text { компаний } \\
\text { аналитиками } \\
\end{array}$ & $\begin{array}{lr}\text { Малое число } & \text { профессиональных } \\
\text { аналитиков, } \\
\text { компании }\end{array}$ & $\begin{array}{l}\text { Широкое освещение компаний } \\
\text { большим числом аналитиков }\end{array}$ \\
\hline
\end{tabular}

Таким образом, можно выделить следующие важные характеристики развивающихся рынков, влияющие на структуру капитала компаний:

- Ограниченный доступ к источникам капитала.

- Высокая асимметрия информации и агентские издержки.

- Высокие макроэкономические риски для инвесторов, созданные макроэкономической нестабильностью, постоянно изменяющейся средой. 


\section{Факторы, определяемые внутренней средой компании}

Среди факторов, определяемых внутренней средой компании, наибольшей специфичностью с точки зрения развивающихся рынков капитала обладают структура собственности и уровень корпоративного управления.

Структура собственности. Компании, работающие на развивающихся рынках капитала, как правило, характеризуются высокой концентрацией собственности. Кроме того, во многих развивающихся странах (например, в Индии), собственниками наиболее крупных компаний являются определенные семьи. Государственное участие в капитале компаний также остается на достаточно высоком уровне. Так, Раджагопал отмечает в Индии высокую, по сравнению с развитыми странами, концентрацию акционерного капитала и контроля, а также распространенность государственной и семейной собственности. Удомсирикул, Джамреорнвонг, Джирапорн наблюдают более высокую концентрация собственности в Таиланде по сравнению с США. Делькур подчеркивает, что в России и Чехии большое количество компаний все еще остается в государственной собственности. Крнигой, Мрамор (Crnigoj, Mramor, 2009) изучают влияние изменений в структуре собственности компаний Словении на структуру их капитала. Влияние высокой концентрации собственности на структуру капитала компаний изучали Сеспендес, Гозалес, Молина.

Корпоративное управление. Компании, работающие на развивающихся рынках капитала, характеризуются низким уровнем корпоративного управления. Зачастую компаниям выгодно объединяться в группы для решения проблем, связанных с несовершенством рынков капитала и высокой асимметрией информации. Кроме того, часто в процесс управления компанией вовлечены родственники или друзья собственников компаний. Данная специфика подчеркивается в работе Маноса, Муринде, Грина (Manos, Murinde, Green, 2007). Исследователи Удомсирикул, Джамреорнвонг, Джирапорн говорят о том, что ряд крупных тайских компаний является частью конгломератов. Делькур также отмечает слабое корпоративное управление в странах с переходной экономикой.

Таблица 2

Специфика некоторых внутренних факторов компании на развивающихся рынках капитала

\begin{tabular}{|c|c|c|}
\hline Фактор & Развивающиеся рынки & Развитые рынки \\
\hline $\begin{array}{l}\text { Структура } \\
\text { собственности }\end{array}$ & $\begin{array}{l}\text { • } \\
\text { Превалирует }\end{array}$ & $\begin{array}{ll}\text { Низкая } & \text { концентрация } \\
\text { собственности }\end{array}$ \\
\hline $\begin{array}{l}\text { Корпоративное } \\
\text { управление }\end{array}$ & $\begin{array}{l}\text { • } \text { Низкий уровень } \\
\text { корпоративного управления } \\
\text { • } \quad \text { Топ менеджерами компаний } \\
\text { зачастую работают родственники и } \\
\text { друзья семей-собственников }\end{array}$ & $\begin{array}{l}\text { - } \text { Высокий } \\
\text { корпоративного управления } \\
\text { - Распространено участие } \\
\text { независимых директоров в } \\
\text { управлении компаниями }\end{array}$ \\
\hline
\end{tabular}

Таким образом, можно выделить следующие специфические внутренние характеристики компании, которые могут оказывать влияние на структуру капитала:

- Высокая концентрация собственности.

- Низкий уровень корпоративного управления.

Далее в статье будет рассмотрена методология исследования структуры капитала компаний и выявлены особенности ее эмпирического анализа на развивающихся рынках капитала. 


\section{Эмпирические исследования структуры капитала компаний, работающих на развивающихся рынках капитала}

\section{Определение левереджа}

В работах, исследующих проблему на развивающихся рынках капитала, предпочтение, как правило, отдается бухгалтерским показателям левереджа, что связано со сложностью получения корректных рыночных данных, a также с высокой волатильностью развивающихся рынков. Так, бухгалтерский показатель используют Ни, Гуо, Джилес (Ni, Guo, Giles, 2010), Делькур, Чакраборти.

Ряд исследователей также используют как бухгалтерское, так и рыночное определения левереджа (например, в работах Удомсирикула, Джамреорнвонга, Джирапорна, Йанга, Ч. Лии, Гу, Й. Лии (Yang et al., 2010)).

Таким образом, с точки зрения методологии определения левереджа специфика исследования структуры капитала компаний, работающих на развивающихся рынках капитала, заключается в основном в сложности применения рыночных определений левереджа и в предпочтении бухгалтерских определений левереджа рыночным.

\section{Методы эмпирического исследования}

В настоящее время наиболее распространены два способа изучения структуры капитала компаний: метод анкетирования и регрессионный анализ данных компании. Исследования структуры капитала компаний развивающихся стран осуществляются в основном при помощи регрессионного анализа, поскольку применение метода анкетирования в этих странах усложняется из-за специфики корпоративного управления и нежелания раскрывать информацию.

Нужно отметить, что регрессионный анализ имеет ряд недостатков. Во-первых, регрессионный анализ дает разные результаты оценки влияния одних и тех же факторов в зависимости от особенностей строящейся модели и данных (например, разные оценки получены в работах Харриса, Равива (Harris, Raviv, 1991) и Титмана и Весселса (Titman, Wessels, 1988). Во-вторых, в регрессионном анализе происходит усреднение данных и, соответственно, потеря всего разнообразия решений в области структуры капитала разнообразие решений подчеркивали Кайо, Кимура (Kayo, Kimura, 2011).

Так как развивающиеся страны еще более неоднородны по сравнению с развитыми, то выявление каких-либо общих зависимостей может быть значительно осложнено ввиду неоднородности компаний разных стран. В связи с этим при анализе результатов существующих эмпирических исследований необходимо учитывать данную специфику.

\section{Обзор некоторых последних эмпирических исследований структуры капитала компаний, работающих на развивающихся рынках капитала}

В данной работе будут рассмотрены некоторые исследования структуры капитала компаний на развивающихся рынках капитала, проведенные в последние годы.

Таблица 3

Методология ряда недавних эмпирических исследований

\begin{tabular}{|c|c|c|c|}
\hline Исследование & Метод & $\begin{array}{c}\text { Определе } \\
\text { ния }\end{array}$ & Резу. \\
\hline \multicolumn{4}{|c|}{ Удомсирикул, Дюсамреорнвонг, Дюсирапорн (Udomsirikul, Jumreornvong, Jiraporn, 2011) } \\
\hline $\begin{array}{l}\text { Страна: } \\
\text { Таиланд }\end{array}$ & $\begin{array}{lr}\text { 1.Расчет коэффициентов } \\
\text { корреляции } & \text { между }\end{array}$ & $\begin{array}{l}\mathrm{BL}= \\
\mathrm{TL} /\end{array}$ & $\begin{array}{lr}\text { Проведен } & \text { анализ } \\
\text { ликвидности } & \text { влияния } \\
\end{array}$ \\
\hline
\end{tabular}




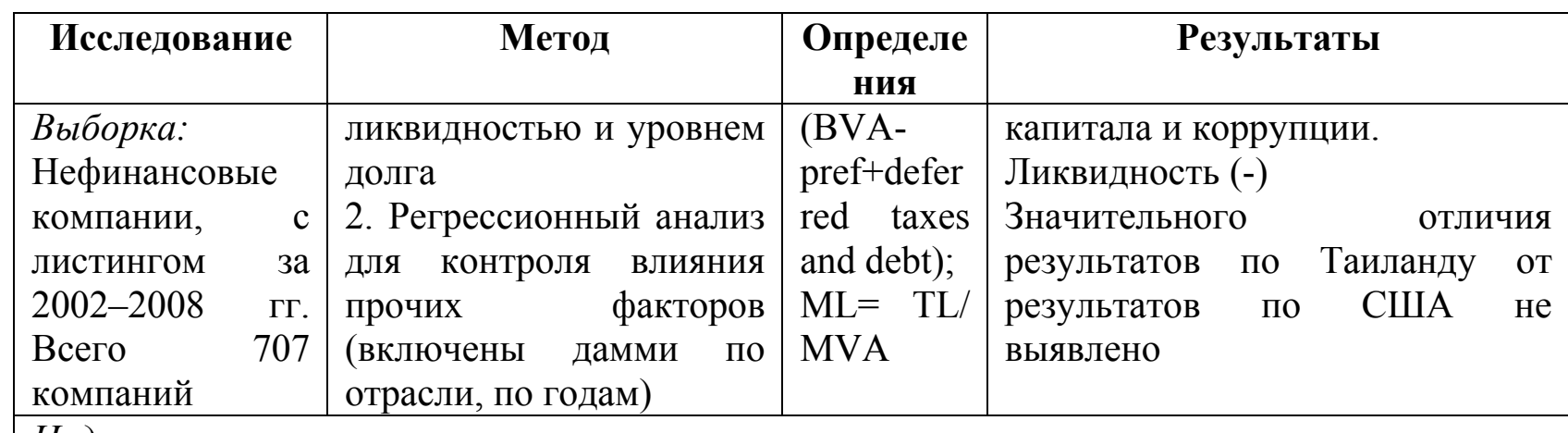

Недостатки:

1. Учитывается влияние факторов, величины которых были взяты за прошлый период, и не учитываются текущие значения переменных (для исключения эндогенности)

Кокорева, Ивашковская, Кадуров (Kokoreva, Ivashkovskaya, Kadurov, 2011)

\begin{tabular}{|c|c|c|c|}
\hline $\begin{array}{l}\text { Страна: Страны } \\
\text { БРИК, а также } \\
\text { Болгария, } \\
\text { Чехия, Эстония, } \\
\text { Хорватия, } \\
\text { Венгрия, Литва, } \\
\text { Латвия, Польша, } \\
\text { Румыния, } \\
\text { Словения } \\
\text { Выборка: } \\
\text { Компании, } \\
\text { суммарной } \\
\text { выручкой более } \\
\text { 100 млн долл. } \\
\text { 2002-2009 гг. } \\
\text { Всего } \\
\text { компании }\end{array}$ & $\begin{array}{l}\text { Динамическая модель } \\
\text { Оценка: } \\
\text { 1. Общий метод } \\
\text { моментов (ОММ) } \\
\text { 2. Одношаговая модель }\end{array}$ & $\begin{array}{l}\text { TDR }= \\
(\mathrm{LTD}+ \\
\mathrm{STD}) /(\mathrm{TD} \\
+\mathrm{BVE})\end{array}$ & 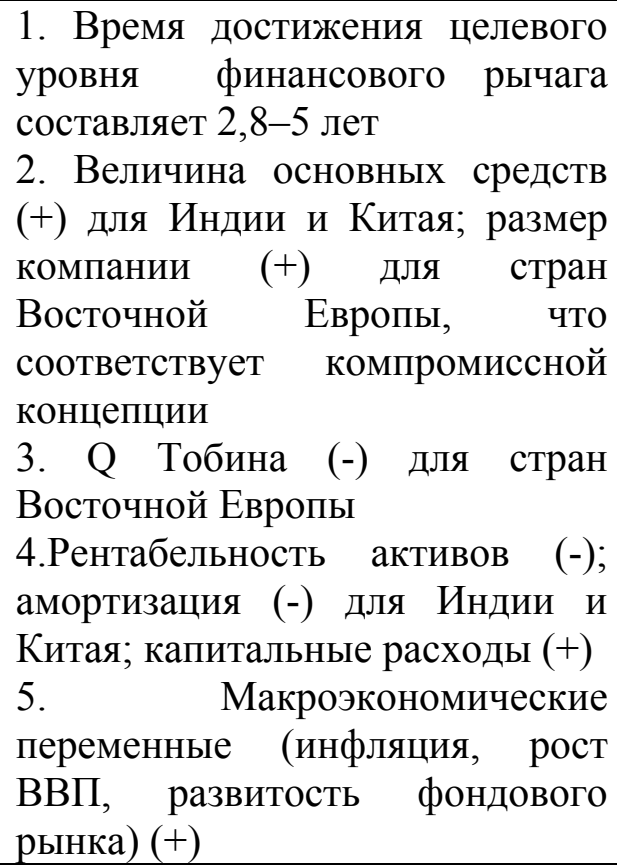 \\
\hline
\end{tabular}

Преимущества:

1. Одношаговая модель позволяет учитывать ненаблюдаемые индивидуальные эффекты, а также одновременно моделировать скорость приспособления и факторы, влияющие на структуру капитала

\section{Чакраборти (Chakraborty, 2010)}

\begin{tabular}{|c|c|c|c|}
\hline $\begin{array}{l}\text { Страна: Индия } \\
\text { Выборка: } 1169 \\
\text { нефинансовых } \\
\text { компаний } \\
\text { (листинг в } 1995- \\
2008 \text { гг.) Всего } \\
16 \\
\text { наблюдений }\end{array}$ & $\begin{array}{l}\text { Регрессионный анализ. } \\
\text { Оценка: } \\
\text { 1.Модифицированный } \\
\text { метод наименьших } \\
\text { квадратов (ММНК) } \\
2 . \quad \text { Общий метод } \\
\text { моментов (ОММ) } \\
\text { (двухступенчатый) }\end{array}$ & $\begin{array}{l}\mathrm{LEV} 1=\mathrm{TL} \\
/ \mathrm{BVA} \\
\mathrm{LEV} 2=\mathrm{TL} \\
/ \\
(\mathrm{TL}+\mathrm{ME})\end{array}$ & $\begin{array}{l}\text { Тестирование теоретических } \\
\text { концепций структуры капитала в } \\
\text { условиях развивающегося рынка } \\
\text { Индии. Найдено подтверждение: } \\
\text { 1. Концепции иерархий } \\
\text { (доходность (-), размер (-)) } \\
\text { 2. Статической компромиссной } \\
\text { концепции (залоговая стоимость } \\
(+), \text { уникальность (-)) }\end{array}$ \\
\hline
\end{tabular}

Преимущества:

1. ММНК позволяет решить проблему взаимосвязи между данными, которая ранее не давала ответа на вопрос: оценивается ли долгосрочная взаимосвязь между долгом и его детерминантами или ложные взаимосвязи, дающие неверный результат

2. Оценки первого и второго метода соответствуют друг другу за исключением переменной 


\begin{tabular}{|c|c|c|c|}
\hline Исс & & & \\
\hline \multicolumn{4}{|c|}{$\begin{array}{l}\text { роста, выраженной как процентное изменение продаж, что свидетельствует о том, что } \\
\text { результаты не чувствительны к методу } \\
\text { 3. ОММ позволяет решить проблему ОМНК, связанную с наличием ненулевой ковариации } \\
\text { между "ненаблюдаемыми" характеристиками компаний и объясняющими переменными } \\
\text { Недостатки: } \\
\text { 1. ОММ: разные тесты дали разные результаты подтверждения коинтеграции (Као (1999) - } \\
\text { не подтвердил коинтеграцию для LEV1 и Pedroni (1999,2004) подтвердил коинтеграцию } \\
\text { для всех уравнений) }\end{array}$} \\
\hline \multicolumn{4}{|c|}{ Сеспендес, Гозалес, Молина (Cespendes, Gozales, Molina, 2010) } \\
\hline $\begin{array}{l}\text { Страна: страны } \\
\text { Латинской } \\
\text { Америки } \\
\text { Выборка: } \\
\text { данные за 1996- } \\
2005 \text { гг. } \\
\text { Всего } \\
\text { компаний, } \\
6766 \\
\text { наблюдений }\end{array}$ & 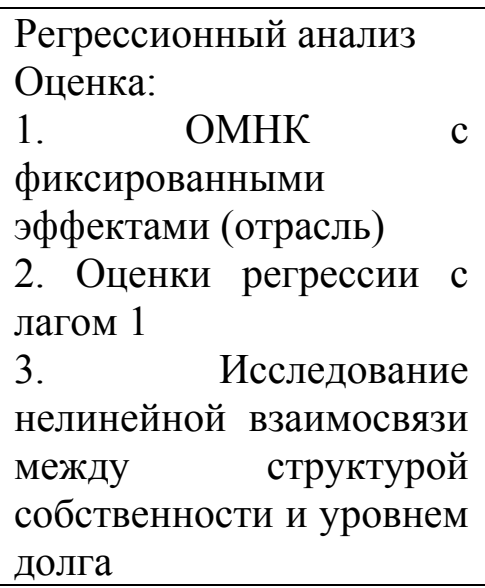 & $\begin{array}{l}\text { Lev1b=TL } \\
/(\mathrm{TL}+ \\
\text { BVE); } \\
\text { Lev2b= } \\
\text { (TFD+TN } \\
\text { O)/(TFD+ } \\
\text { TNO+BV } \\
\text { E); } \\
\text { Lev2m(ан } \\
\text { алогично) }\end{array}$ & 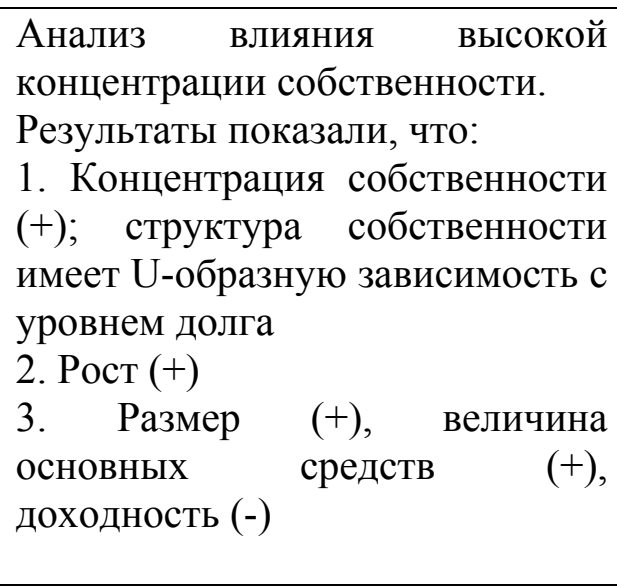 \\
\hline
\end{tabular}

Недостатки:

1. Оценка влияния структуры собственности по странам в отдельности выявила аналогичные зависимости, но коэффициенты были значимы только для Бразилии и Чили, так как в этих странах больше всего наблюдений

2. Относительно низкое количество наблюдений в Аргентине (21), Колумбии (82), Венесуэле (43), что снижает статистическую силу оценок

Йанг, Ч. Лии, Гу, Й.Лии (Yang, Lee, Gu, Lee, 2010)

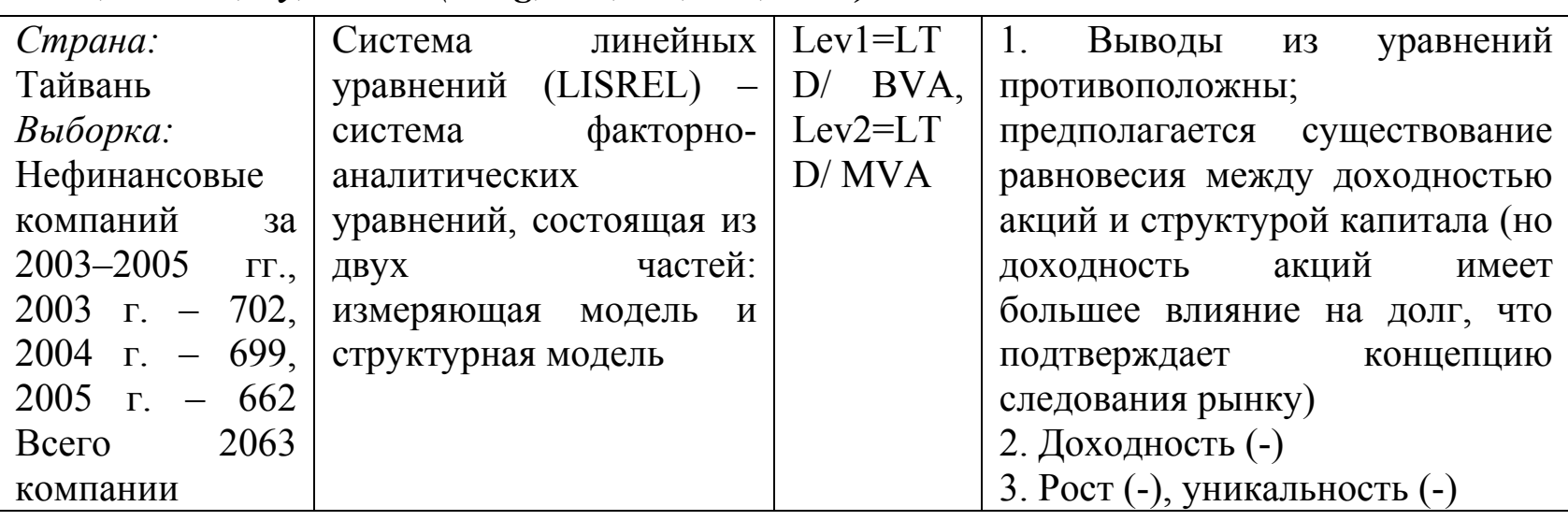

Преимущества:

1. Возможность исследования взаимовлияния двух эндогенных переменных

2.Ненаблюдаемые специфические признаки компании оцениваются через наблюдаемые переменные

Недостатки:

1. Короткий период исследования

2.Определение левереджа может искажать результаты, т.к. знаменатель включает нефинансовый долг

3. Сложная спецификация модели может привести к некорректным результатам (с этой проблемой столкнулись Titman и Wessels (1988) -первые применившие данную модель для 


\begin{tabular}{|c|c|c|c|}
\hline Исследование & Метод & $\begin{array}{c}\text { Определе } \\
\text { ния }\end{array}$ & Результаты \\
\hline \multicolumn{4}{|l|}{ анализа СК) } \\
\hline \multicolumn{4}{|c|}{ Вy, Йу (Wu, Yue, 2009) } \\
\hline $\begin{array}{l}\text { Страна: Китай } \\
\text { Выборка: } \\
\text { Всего } 2182 \\
\text { наблюдений. } \\
2001-2003 \text { гг. - } \\
464 \text { наблюдения, } \\
\text { в } 1999 \text { г. }-372, \\
\text { в } 2000 \text { г. }-418\end{array}$ & $\begin{array}{lr}\text { Регрессия } & \text { c } \\
\text { переменными, которые } \\
\text { представляют } \\
\text { изменение собой } \\
\text { (first } \quad \text { ва } \\
\text { regression) }\end{array}$ & $\begin{array}{l}\text { Lev1=TL/ } \\
\text { BVA }\end{array}$ & $\begin{array}{l}\text { Компании, пользовавшиеся } \\
\text { налоговыми льготами, } \\
\text { увеличили левередж на } 3,3 \% \text { в } \\
\text { течение трех лет после отмены } \\
\text { льгот в сравнении с другими } \\
\text { компаниями } \\
1 . \text { Доступ к кредитам (+); рост } \\
(+) ; \text { доходность (-); размер (+, но } \\
\text { значим только в трех годах) }\end{array}$ \\
\hline \multicolumn{4}{|c|}{$\begin{array}{l}\text { Преимущества: } \\
\text { 1. Учитывается влияние изменений переменных, а не их величин, что решает проблему } \\
\text { смещенных оценок из-за недоучета каких-либо переменных } \\
\text { Недостатки: } \\
\text { 1. Предполагается, что компании корректируют структуру капитала, так как их цель - } \\
\text { увеличение богатства акционеров, однако в выборку входят компании, собственником } \\
\text { которых является государство, и которые могут не соответствовать этому принципу, что } \\
\text { будет давать искаженные оценки }\end{array}$} \\
\hline \multicolumn{4}{|c|}{ Манос, Муринде, Грин (Manos, Murinde, Green, 2007) } \\
\hline $\begin{array}{l}\text { Страна: Индия } \\
\text { Выборка: } 1652 \\
\text { котируемые } \\
\text { компании, } \\
\text { Данные за } 2000 \\
\text { год }\end{array}$ & $\begin{array}{l}\text { Перекрестная регрессия } \\
\text { (пересечение факторов с } \\
\text { GP - дамми-переменной, } \\
\text { определяющей } \\
\text { принадлежность } \\
\text { группе) } \\
\text { Оценка: } \\
\text { 1. ОМНК } \\
\text { 2. Пробит } \\
\text { бинарного модель } \\
\text { (ПМБВ) } \\
\end{array}$ & $\begin{array}{l}\mathrm{L}=\mathrm{TL} / \\
\mathrm{MVA} \\
\mathrm{GP} \\
\text { дамми } \quad(1 \\
-\quad \text { входит } \\
\text { в группу; } \\
0-\text { нет) }\end{array}$ & $\begin{array}{l}\text { 1. Значительную роль играет } \\
\text { наличие внутригруппового } \\
\text { рынка капитала и доступа к } \\
\text { государственным } \\
\text { иностранным кредитам } \\
\text { 2. Компании, входящие в } \\
\text { группы, менее чувствительны к } \\
\text { традиционным переменным } \\
\text { 3. Групповые переменные все } \\
\text { значимы }\end{array}$ \\
\hline \multicolumn{4}{|c|}{$\begin{array}{l}\text { Преимущества: } \\
\text { 1. ПМБВ позволяет четче определить разницу в возможностях привлечения } \\
\text { государственного и иностранного долга между компаниями, входящими в группы, и } \\
\text { работающими индивидуально } \\
\text { Недостатки: } \\
\text { 1.Период исследования очень короткий (один год) }\end{array}$} \\
\hline \multicolumn{4}{|c|}{ Делькур (Delcure, 2007) } \\
\hline $\begin{array}{l}\text { Страна: Чехия, } \\
\text { Польша, Россия, } \\
\text { Словакия } \\
\text { Выборка: } \\
\text { Данные за 1996- } \\
2002 \text { гг. Всего } \\
22 \text { - Чехия, } \\
61 \text { - Польша, } \\
33 \text { - РФ, } \\
13 \text { - Словакия }\end{array}$ & $\begin{array}{l}\text { Регрессионный анализ } \\
\text { Оценка: } \\
\text { 1. ОМНК } \\
\text { 2.Фиксированные } \\
\text { эффекты } \\
\text { 3.Случайные эффекты }\end{array}$ & $\begin{array}{l}\text { TL=TL/B } \\
\text { VA; LTL } \\
=\text { LTD/ } \\
\text { BVA; } \\
\text { STL = } \\
\text { STD/ } \\
\text { BVA }\end{array}$ & $\begin{array}{l}\text { 1. Подтверждается } \\
\text { модифицированная концепция } \\
\text { иерархий } \\
\text { 2. Размер (+) с STL, Размер (-) с } \\
\text { LTL для Чехии, Польши и } \\
\text { Словакии. В РФ Размер (+) с } \\
\text { LTL Залоговая стоимость (+) } \\
\text { 3. Недолговые налоговые щиты } \\
\text { (+) } \\
\text { 4. Риск (-) для РФ и Чехии } \\
\text { 5. Налоги (+) }\end{array}$ \\
\hline
\end{tabular}




\begin{tabular}{|c|c|c|c|}
\hline Исследование & Метод & $\begin{array}{c}\text { Определе } \\
\text { ния }\end{array}$ & Результаты \\
\hline \multicolumn{4}{|c|}{$\begin{array}{l}\text { Преимущества: } \\
\text { 1. Учитывает влияние фиксированных и случайных эффектов, что позволяет дать } \\
\text { несмещенные оценки }\end{array}$} \\
\hline
\end{tabular}

TL - суммарный долг; FD - финансовый долг; LTL и STL - долгосрочный и краткосрочный долги соответственно; BVA и MVA - бухгалтерская и рыночная стоимость суммарных активов соответственно; BE и MVE - бухгалтерская и рыночная стоимость собственного капитала соответственно; TNO - total negotiable obligations.

Удомсирикул, Джамреорнвонг, Джирапорн попытались определить влияние ликвидности собственного капитала на уровень долга и влияние коррупции, которая, по предположению авторов, должна была снижать эффект от ликвидности. В результате была получена отрицательная взаимосвязь между ликвидностью и уровнем долга, причем результаты по Таиланду не отличаются от результатов по США, следовательно, специфические факторы развивающихся рынков не оказывают существенного влияния на взаимосвязь между ликвидностью и уровнем долга. Однако Алвес, Феррейра (Alves, Ferreira, 2011), исследовавшие данные компаний из 31 страны, включая 10 развивающихся стран, всего 21804 наблюдения по 5699 компаниям, показали, что в странах с более высокой коррупцией уровень левереджа также более высокий. Кроме того, исследователи выявили, что факторы, определяющие характеристики компании, имеют схожие степени воздействия во всех странах. Особенно явно это видно на таком факторе, как доходность, что свидетельствует о высокой значимости концепции иерархий по всему миру. Однако проблемы асимметрии информации более выражены в странах с меньшей защитой прав акционеров.

Проблемы коррупции изучали Окере, Тамуле, Малоней, которые сделали акцент на факторы, влияющие на привлечение иностранного финансирования в компании развивающихся стран. Анализ одиннадцати развивающихся стран (Египет, ЮАР, Индия, Венгрия, Турция, Бразилия, Мексика, Филиппины, Марокко, Румыния, Чили) показал, что в странах с более высоким уровнем коррупции и слабой правовой защитой акционеров в структуре капитала компаний преобладает краткосрочное долговое финансирование.

Чакраборти пишет о том, что в Индии процессы либерализации и развития рынков капитала могут влиять на структуру капитала компаний. Исследователь находит подтверждение концепции иерархий, а также статической компромиссной концепции. Однако недолговые налоговые щиты оказывают положительное влияние, что противоречит компромиссной концепции. Спорным также остается направление влияния «роста», но в большинстве случаев подтверждается тот факт, что растущие индийские компании привлекают больше внешнего капитала. Агентская теория малоприменима. Таким образом, на развивающихся рынках капитала применимы теоретические концепции, используемые на развитых ранках.

Исследование И.В. Ивашковской и П.В. Макарова (Ивашковская, Макаров, 2010) показало существование неоднозначного отношения к концепциям и отсутствие какой-либо доминирующей концепции, максимально точно объясняющей изменения в структуре капитала. В работе был проведен регрессионный анализ данных за период с 2004 по 2008 год по компаниям из 10 стран Центральной и Восточной Европы - Польши, Болгарии, Словении, Хорватии, Румынии, Литвы, Венгрии, Латвии, Эстонии, Чехии. Результаты исследования выявили как влияние факторов, соответствующее компромиссной концепции (доля материальных активов и размер капитала), так и наличие взаимосвязей, соответствующих концепции иерархий (отрицательная зависимость доходности капитала от уровня финансового рычага).

Сеспендес, Гозалес, Молина анализируют воздействие высокой концентрации собственности, низких возможностей для использования выгод от налогового щита и 
высоких издержек банкротства, а также волатильности экономики на уровень долга. Результаты исследования показали, что более высокая концентрация собственности способствует более высокому левереджу, что объясняется нежеланием акционеров терять контроль. Структура собственности U-образная. Кроме того, выявлено, что рост имеет положительный коэффициент, поскольку в отличие от других стран, в странах Латинской Америки растущие компании избегают выпускать акции.

Йанг, Ч.Лии, Гу, Й.Лии нашли подтверждение концепции следования рынку в Таиланде. Однако система уравнений, использованная для анализа взаимовлияния доходности акций и структуры капитала, дала противоположные результаты, поэтому можно предположить, что существует некое равновесие: когда доходность высока, компании снижают долг, что, в свою очередь, приводит к снижению доходности и необходимости снова наращивать долг. Кроме того, найдено частичное подтверждение концепции иерархий и компромиссной концепции.

Ву, Йу изучили исключительный случай, в котором центральное правительство Китая отменило политику по налоговым скидкам регионального правительства, что способствовало росту уровня долга в этих компаниях, причем корректировка левереджа была более значительной в компаниях, имеющих больший доступ к банковским кредитам. Таким образом, исследование позволило более четко определить взаимосвязь между налогами и структурой капитала, что сложно сделать на примере развитых стран с устоявшейся налоговой системой.

В работе Маноса, Муринде, Грина подчеркивается, что индийские компании объединяются в группы и, как правило, управляются членами какой-либо одной семьи с целью смягчения асимметрии информации, агентских издержек, рисков и т.п. Выявлено, что структура капитала компаний, входящих в группы, значительно отличается из-за существования внутреннего рынка капитала и доступа к государственным и иностранным кредитам.

Делькур провела анализ Чехии, Польши, России, Словакии и нашла подтверждение модифицированной концепции иерархий. Данный результат свидетельствует о том, что неразвитость долговых рынков делает более простым источником привлечение выпуск собственного капитала. Кроме того, если в Чехии, Польше и Словакии выявлена положительная зависимость между размером компании и краткосрочным долгом и отрицательная - между размером и долгосрочным долгом, то в России последняя взаимосвязь является также положительной, что может быть связано с регулированием и государственной финансовой поддержкой крупных компаний. В работе также выявлена отрицательная взаимосвязь между риском и уровнем долга для Российской Федерации и Чехии, что соответствует компромиссной концепции и может быть объяснено тем, что в России закон о банкротстве начал работать только с 1998 года, а в Чехии плохо защищены права кредиторов. Похожие результаты получили Стефан, Талавера, Цапин, которые доказали, что украинские компании с ограниченным доступом к финансовым ресурсам привлекают краткосрочные кредитные средства.

Бокпин (Bokpin, 2009) провел анализ данных компаний из 34 развивающихся рынков за период с 1990 по 2006 год и подтвердил влияние макросреды на структуру капитала компаний. В частности, была выявлена отрицательная взаимосвязь между ВВП и уровнем левереджа и положительная взаимосвязь между инфляцией и уровнем левереджа. Кроме того, исследователь пришел к выводу, что степень развитости рынка акций не оказывает существенного влияния на структуру капитала, в то время как степень развитости банковской сферы имеет существенное значение. Значимость специфических суверенных факторов подтвердили исследователи Антонио, Гуней, Подьял (Antoniou, Guney, Paudyal, 2008). Джонг, Кабир, Нгйен (Jong, Kabir, Nguyen, 2008) сравнивали структуры капитала компаний, оперирующих в разных странах, учитывая влияние таких факторов, как ВВП, развитость фондовых рынков, степень защищенности инвесторов и т.п.

Таким образом, исследователи находят подтверждение существующих теоретических 
концепций на развивающихся рынках: наиболее часто подтверждается применение концепции иерархий, как в традиционной, так и в модифицированной форме. Существование модификации вызвано неразвитостью рынков заемного капитала в рассматриваемых странах. Исследователи также находят подтверждение компромиссной концепции и концепции следования рынку. Относительно агентской теории выводы являются спорными, поскольку многие исследователи делают акцент на том, что решение агентских проблем в развивающихся странах решается за счет высокой концентрации собственности и семейного владения и управления бизнесом.

Основная специфика методологии исследования заключается в том, что:

- определение факторов, анализ и построение гипотез производятся с учетом влияния специфических характеристик развивающихся рынков;

- исследование происходит при условии изменения факторов: рост эффективности рынков капитала; усовершенствование законодательства; изменения в налоговых льготах и т.п.

\section{Выводы}

В данной работе представлен краткий обзор ряда последних эмпирических исследований структуры капитала компаний на развивающихся рынках. Определено, что наиболее существенными с точки зрения процесса формирования структуры капитала компаний являются такие черты развивающихся рынков, как ограниченный доступ к рынкам капитала, высокая асимметрия информации, экономическая нестабильность, низкая правовая защита, высокая коррупция и концентрация собственности, слабая система корпоративного управления. Для исследования структуры капитала компаний на развивающихся рынках используется в основном бухгалтерское определение левереджа (из-за недостатка и высокой волатильности рыночных данных). Определение факторов, анализ и построение гипотез производятся с учетом влияния специфических характеристик развивающихся рынков, причем исследование происходит при условии изменения факторов. Большинство эмпирических работ подтвердило применение концепции иерархий, которая может принимать модифицированный вид. Существование модификации вызвано неразвитостью рынков заемного капитала в рассматриваемых странах. Во многих работах найдено подтверждение выводов компромиссной концепции и концепции следования рынку.

\section{Список литературы}

1. Ивашковская И.В., Макаров П.В. Действуют ли классические концепции выбора структуры капитала на развивающихся рынках? Эмпирический анализ компаний Восточной и Центральной Европы // Корпоративные финансы. 2010. № 15. С. 47-62.

2. Ивашковская И., Солнцева М. Структура капитала в российских компаниях как стратегическое решение // Вестник Санкт-Петербургского Университета. 2008. Вып. 3.

3. Солодухина А.В., Репин Д.В. В поисках решения загадки структуры капитала: поведенческий подход // Корпоративные финансы. 2008. № 1(5). С. 103-118.

4. Alves, P.F.P., Ferreira, M.A. (2011), Capital structure and law around the world, Journal of Multinational Financial Management, 21 (2011) 119-150.

5. Ameer, R. (2010), Financial liberalization and firms' capital structure adjustments evidence from Southeast Asia and South America, Journal of Economics and Finance, Online First. URL: http://rd.springer.com/article/10.1007/s12197-010-9158-3\#.

6. Antoniou, A., Guney, Y., and Paudyal, K. (2008), The determinants of capital structure: Capital market-oriented versus bank-oriented institutions, Journal of Financial and Quantitative Analysis, 43 (2008) 59-92.

7. Bhaduri, S.M. (2002), Determinants of Capital Structure Choice: A Study of the Indian 
Corporate Sector, Applied Financial Economics, 12 (2002) 655-665.

8. Bokpin, G.A. (2009), Macroeconomic development and capital structure decisions of firms. Evidence from emerging market economies, Studies in Economics and Finance, 2(26) (2009) 129-142.

9. Céspedes, J., González, M., and Molina, C.A. (2010), Ownership and capital structure in Latin America, Journal of Business Research, 63 (2010) 248-254.

10. Chakraborty, I. (2010), Capital structure in an emerging stock market: The case of India, Research in International Business and Finance, 24 (2010) 295-314.

11. Crnigoj, M., and Mramor, D. (2009), Determinants of Capital Structure in Emerging European Economies: Evidence from Slovenian Firms, Emerging Markets Finance \& Trade, 1(45) (2009) 72-89.

12. De Jong, A., Kabir, R., and Nguyen, T.T. (2008), Capital structure around the world: The roles of firm- and country-specific determinants, Journal of Banking and Finance, 32 (2008) 1954-1969.

13. Delcoure, N. (2007), The determinants of capital structure in transitional economies. International Review of Economics and Finance, 16 (2007) 400-415.

14. Eldomiaty, T. I. (2008), The Validity and Sensitivity of Debt Signaling Hypothesis in Transitional Market: Perspectives from Egypt, International Research Journal of Finance and Economics, 14 (2008) 122-140.

15. Fernandes, N. (2011), Global convergence of financing policies: Evidence for emergingmarket firms, Journal of International Business Studies, 8(42) (2011) 1043-1059.

16. Harris, M., and Raviv, A. (1991), The Theory of Capital Stmctuie, Journal of Finance, 46 (1991) 297-356.

17. Harvey, C., Lins K., and Roper, A. (2004), The Effect of Capital Structure When Expected Agency Costs are Extreme, Journal of Financial Economics, 74 (2004) 3-30.

18. Ivashkovskaya, I., and Solntseva, M. (2009), Capital Structure Choice in BRIC: Do Russian, Brazilian and Chinese Firms Follow Pecking Order or Trade-Off Logic of Financing. Business Strategies and Technological Innovations for Sustainable Development: Creating Global Prosperity for Humanity// Global Business and Technology Association Eleventh International Conference Readings Book, Edited by N. Delener, L.Fuxman, F.V.Lu, A.Putnova, L.E.Rivera-Solis. N.Y., (2009) 572-580.

19. Kayo, E.K., and Kimura, H. (2011), Hierarchical Determinants of Capital Structure, Journal of Banking \& Finance, 35 (2011) 358-371.

20. Kokoreva, M. S., Ivashkovskaya, I.V., and Kadurov, A.A. (2011), Capital Structure Policy in Central Europe and BRIC: Interaction of Internal Determinants and Macroeconomic Factors// Proceedings of the 19th Annual Conference on Marketing and Business Strategies for Central \& Eastern Europe. (Vienna, 1-3 December 2011). P. 173-189.

21. Lopes, A.B., and de Alencar, R.C. (2010), Disclosure and cost of equity capital in emerging markets: The Brazilian case, The International Journal of Accounting, 45 (2010) 443-464.

22. Manos, R., Murinde, V., and Green, C.J. (2007), Leverage and business groups: Evidence from Indian firms, Journal of Economics and Business, 59 (2007) 443-465.

23. Ojah, K., and Pillay, K. (2009), Debt markets and corporate debt structure in an emerging market: The South African example, Economic Modelling, 26 (2009) 1215-1227.

24. Okere, V.O., Tamule, H.B., and Maloney, P.J. (2010), Capital Structure, Institutional Quality Index and Valuation of Projects in Emerging Markets, Journal of International Business and Economic, 1(10) (2010) 25-40.

25. Rajagopal S. (2011), The portability of capital structure theory: Do traditional models fit in an emerging economy? Journal of Finance and Accountancy, (2011) 1-17.

26. Stephan A.,Talavera O., and Tsapin A. (2011), Corporate debt maturity choice in emerging financial markets, The Quarterly Review of Economics and Finance, 51 (2011) 141-151.

27. Titman, S., and Wessels, R. (1988), The Determinants of Capital Structure Choice, Journal of Finance, 43 (1988) 1-21. 
28. Udomsirikul, P., Jumreornvong, S., Jiraporn, P. (2011), Liquidity and capital structure: The case of Thailand, Journal of Multinational Financial Management, 21 (2011) 106-117.

29. Welch, I. (2011), Two Common Problems in Capital Structure Research: The FinancialDebt-To-Asset Ratio and Issuing Activity Versus Leverage Changes, International Review of Finance, 1(11) (2011) 1-17.

30. Wu, L., and Yue, H. (2009), Corporate tax, capital structure, and the accessibility of bank loans: Evidence from China, Journal of Banking \& Finance, 33 (2009) 30-38.

31. Yang, N., Shasha, G., and Giles, D.E. (2010), Capital structure in an emerging market: a duration analysis of the time interval between IPO and SEO in China, Applied Financial Economics, 20 (2010) 1531-1545.

32. Yang, C-C., Lee, C., Gu Y.-X., and Lee, Y.-W. (2010), Co-determination of capital structure and stock returns - A LISREL approach. An empirical test of Taiwan stock markets, The Quarterly Review of Economics and Finance, 50 (2010) 222-233. 